\title{
PENGARUH PEMBERIAN INSULIN-LIKE GROWTH FACTOR-I (IGF-I) DARI SERUM KUDA CROSSBREED BUNTING TERHADAP KETEBALAN ENDOMETRIUM MENCIT (Mus musculus)
}

\section{EFFECT OF INSULIN-LIKE GROWTH FACTOR-I (IGF-I) DERIVED FROM PREGNANT CROSSBREED MARE SERUM ON ENDOMETRIUM THICKNESS OF MICE (Mus musculus)}

\author{
Dyah Ayu Roro Risna $\mathbf{Y}^{1)}$, Sri Mulyati ${ }^{2)}$, Roesno Darsono ${ }^{3)}$, Imam Mustofa ${ }^{4}$, \\ Arimbi ${ }^{5)}$, Widjiati6) \\ ${ }^{1)}$ Student, ${ }^{2,4)}$ Veterinary Reproduction Department, ${ }^{3,5}$ Veterinary Patology Department, \\ ${ }^{6)}$ Veterinary Anatomy Departement \\ Faculty of Veterinary Medicine, Airlangga University \\ email: dyah.risna@gmail.com
}

\begin{abstract}
The purpose of the research was to know the effect of Insulin-Like Growth Factor-I (IGFI) derived from pregnant crossbreed mare serum (PMS) on endometrium thickness of mice (Mus musculus). The subject of this research were 35 female mice. The research was arranged by Completely Randomized Design (CRD) with seven treatment and five replications. The treatment were $\mathrm{P} 0=10 \mathrm{ng} / \mathrm{ml}$ of physiological NaCl, P1 $1_{1}=10 \mathrm{ng} / \mathrm{ml}$ of IGF-I PMS, $\mathrm{P} 1_{2}=20$ ng/ml of IGF-I PMS, P1 $1_{3}=40 \mathrm{ng} / \mathrm{ml}$ of IGF-I PMS, P $2_{1}=10 \mathrm{ng} / \mathrm{ml}$ of IGF-I recombinant mouse, $\mathrm{P} 2_{2}=20 \mathrm{ng} / \mathrm{ml}$ of IGF-I recombinant mouse, and P2 $2_{3}=40 \mathrm{ng} / \mathrm{ml}$ of IGF-I recombinant mouse. Observed variables include histopatological endometrium thickness of mice. The data were analyzed by Analysis of Variance (ANOVA), followed by HSD (Honestly Significant Difference) test. The data was also be analyzed using General Linear Model Univarieted to see the comparison between IGF-I PMS and recombinant mouse. The result showed that the addition of IGF-I PMS did not significantly affect $(p>0,05)$ on endometrium thickness of mice . It showed that did not significantly difference $(p>0,05)$ between the effect of IGF-I PMS and IGF-I recombinant mouse against the endometrium thickness of mice.
\end{abstract}

Key words: IGF-I, IGF-I pregnant crossbreed mare serum, endometrium thickness, Mus musculus.

\section{Pendahuluan}

Indonesia merupakan negara agraris dengan potensi sumber daya alam yang melimpah, dimana komoditas yang diunggulkan berada pada sektor pertanian dan peternakan. Namun kendala yang ditemui dalam usaha pemenuhan kapasitas produksi ternak adalah gangguan reproduksi betina yang menyebabkan rendahnya angka kebuntingan sehingga sulit mencapai tingkat reproduktivitas yang tinggi.

Salah satu yang menjadi masalah pada bagian reproduksi adalah terjadinya kegagalan implantasi, proses implantasi sendiri yaitu upaya embrio untuk mengadakan hubungan langsung dengan dinding uterus sehingga terjadi hubungan yang erat antara embrio dengan dinding uterus induknya (Acache, 2006). Faktor yang perlu dijadi- kan perhatian yakni kondisi tipisnya endometrium, penyebab penipisan dinding endometrium umumnya disebabkan oleh beberapa hal yaitu kadar estrogen yang rendah, aliran darah menuju endometrium kurang memadai, adanya fibroid uterus, terjadinya penyempitan arteri ke endometrium, dan kerusakan pada jaringan endometrium karena kondisi medis tertentu (Bearden, 2004).

Berbagai macam solusi dikembangkan untuk mengatasi keadaan tipisnya endometrium, pemilihan solusi lebih difokuskan pada bioaktif dimana efek samping yang ditimbulkan sedikit atau bahkan tidak berefek samping, salah satu bahan bioaktif yang mempunyai peran dalam reproduksi hewan betina adalah Insulin-Like Growth Factor-I (IGF-I). Insulin-Like Growth Fac- 
tor-I (IGF-I) merupakan famili dari insulin yang berbentuk peptide. IGF-I dan IGF-II memiliki potensi mitogenik dan diferensiasi dari Growth Factor. Pada babi estrogen dan progesteron merangsang uterus untuk menskeresi Insulin-Like Growth Factor-I $(I G F-I)$ dan menunjukkan bahwa estrogen mengatur ekspresi IGF-I didalam uterus ( Oner et al., 2007).

\begin{abstract}
Alat dan Bahan
Alat dan bahan yang digunakan pada penelitian ini adalah Insulin-like Growth Factor-I (IGF-1), Insulin-Like Growth Factor-I (IGF-1) recombinant mouse paten, pewarna Hematoxylin Eosin (HE), $\mathrm{NaCl}$ fisiologis, aquadest, buffer formalin $10 \%$ untuk fiksasi, alkohol (70\%, 80\%, 96\%), litter, pakan dan minum mencit. Spuit disposable syringe $1 \mathrm{ml}$ (One Med), scapel steril, gunting bedah streril, pinset, tatakan gabus, pot organ, object glass (Citoplus, REF 0303-0024), cover glass, kertas label, tissue, mikroskop (Nikon H600L), dan opticlab (Camera DS F1230).
\end{abstract}

\section{Metode Penelitian \\ Tahap Penentuan Dosis}

Penentuan dosis menurut Wang (2006), penggunaan IGF-I SKB dan IGF-I recombinant mouse dengan dosis $10 \mathrm{ng} / \mathrm{ml}$ secara subkutan memberi hasil yang signifikan pada peningkatan resorbsi tulang dalam mempertahankan massa tulang yang normal dan merangsang osteoklastogenesis pada mencit, maka dalam penelitian ini penggunaan dosis IGF-I SKB dan IGF-I recombinant mouse masing-masing sebesar 10 $\mathrm{ng} / \mathrm{ml}$, dengan modifikasi dosis $20 \mathrm{ng} / \mathrm{ml}$, dan $40 \mathrm{ng} / \mathrm{ml}$.

\section{Tahap Pemberian Perlakuan}

Injeksi menggunakan IGF-I SKB dan IGF-I recombinant mouse dilakukan secara subkutan 1 kali sehari pada jam 09.00 WIB selama 5 hari (1 siklus estrus). Perlakuan kontrol diinjeksi dengan $0,1 \mathrm{ml} \mathrm{NaCl}$ Fisiologis secara subkutan. Kelompok perlakuan $\mathrm{P} 1\left(\mathrm{P} 1_{1}, \mathrm{P} 1_{2}, \mathrm{P} 1_{3}\right)$ diinjeksi dengan Insulin-Like Growth Factor-I (IGF-I) dari serum kuda crossbreed bunting (SKB) dan dibagi lagi menjadi 3 dosis $10 \mathrm{ng} / \mathrm{ml}, 20$ $\mathrm{ng} / \mathrm{ml}, 40 \mathrm{ng} / \mathrm{ml}$. Kelompok perlakuan P2 $\left(\mathrm{P} 2_{1}, \mathrm{P} 2_{2}, \mathrm{P} 2_{3}\right)$ diinjeksi dengan IGF-I paten (recombinant mouse) dan dibagi lagi menjadi 3 dosis $10 \mathrm{ng} / \mathrm{ml}, 20 \mathrm{ng} / \mathrm{ml}, 40$ ng/ml. Setiap kelompok kontrol dan kelompok perlakuan terdiri dari 5 ekor mencit. Sebelum dilakukan injeksi IGF-I SKB dan IGF-I recombinant mouse, dilakukan pemeriksaan ulas vagina untuk menentukan fase siklus estrus dari mencit tersebut. Pada hari keenam atau satu hari setelah penyuntikan yang terakhir dilakukan ulas vagina untuk mengetahui pengaruhnya terhadap siklus estrus selama 5 hari (1 siklus birahi), namun hanya dilakukan sekali itu saja. Setelah penyuntikan kedua mulai diperiksa ulas vaginanya selama 10 hari (2 siklus birahi) yang dilakukan setiap 6 jam sekali (Sulisdiani, 2016).

Pada hari ke -12 uterus diambil dengan melakukan eutanasi pada mencit kemudian dilakukan pembedahan untuk pengambilan organ yang digunakan dalam pembuatan preparat histopatologi.

Tahap Pemeriksaan laboratorium struktur histopatologis uterus pada mencit (Mus musculus)

Mencit (Mus musculus) dieutanasi dengan cara dianastesi dengan eter hingga mati (Singh and Krishna, 2010). Kemudian abdomen dibuka, diambil uterus nya dengan hati-hati dengan cara menggunting tepat pada bagian istmus tuba falopii kanan (yaitu bagian yang paling dekat dengan uterus), dan pada bagian ekor (batas antara cevix dan uterus), kemudian langsung dibersihkan. Selanjutnya segera dimasukkan kedalam botol yang berisi larutan fiksasi buffer formalin 10\%, direndam selama 12-14 jam (Modifikasi Douglas W. Cromey, 2004).

\section{Tahap Pengamatan Sediaan Histopato- logi}

Pengukuran ketebalan endometrium dilakukan menggunakan Software Nikkon Image System Optilab, dengan perbesaran lensa okuler 10x dan perbesaran lensa objektif 10x. Pengamatan dilakukan pada kedua kelompok, yakni kontrol dan perlakuan. Pada setiap satu sayatan dilakukan 4 kali ulangan pengukuran, yaitu bagian atas, bawah, kiri dan kanan. (Modifikasi Muchsin, 2009). 


\section{Hasil dan Pembahasan}

Hasil pemeriksaan ketebalan lapisan endometrium mencit setelah diberi perlakuan Insulin-Like Growth Factor-I (IGF-I) dari serum kuda crossbreed bunting (SKB) dan Insulin-Like Growth Factor-I (IGF-I) dari recombinant mouse menunjukkan adanya peningkatan ketebalan lapisan endometrium. Namun dari hasil analisis statistik menunjukkan pemberian IGF-I SKB dan IGF-I recombinant mouse tidak berbeda nyata $(\mathrm{p}>0,05)$ pada ketebalan lapisan endometrium pada perlakuan $\mathrm{P} 1_{1}, \mathrm{P} 1_{2}$, dan $\mathrm{P} 1_{3}$ dan $\mathrm{P} 2_{1}, \mathrm{P} 2_{2}$, dan $\mathrm{P} 2_{3}$. Data hasil pemeriksaan ketebalan lapisan endometrium setelah diinjeksi IGF-I SKB dapat dilihat pada Tabel 4.1 dan grafik perubahan ketebalan lapisan endometrium setelah diinjeksi IGF-I SKB dapat dilihat pada Gambar 1, sedangkan hasil visualisasi jaringan uterus yang memperlihatkan ketebalan lapisan endometrium pada perlakuan yang diinjeksi IGF-I SKB dapat dilihat pada Gambar 2 dan Gambar 3 untuk yang diinjeksi IGF-I recombinant mouse.
Berdasarkan hasil pengamatan pada gambar 1, gambar 2, gambar 3 dapat diketahui bahwa perlakuan (P1) menunjukkan lapisan endometrium paling tebal adalah pada perlakuan ke-1 dengan dosis $10 \mathrm{ng} / \mathrm{ml}$ IGF-I SKB dan dosis 10 $\mathrm{ng} / \mathrm{ml}$ IGF-I recombinant mouse. Pada perlakuan ke-2 dengan dosis $20 \mathrm{ng} / \mathrm{ml}$ dan ke-3 dengan dosis $40 \mathrm{ng} / \mathrm{ml}$ IGF-I SKB dan IGF-I recombinant mouse tidak terjadi pening-katan yang tinggi pada ketebalan lapisan endometrium.

\section{Pembahasan}

Hasil penelitian pemberian IGF-1 Insulin-Like Growth Factor-I (IGF-I) dari serum kuda crossbreed bunting (SKB) dan IGF-1 Insulin-Like Growth Factor-I (IGF-I) recombinant mouse dapat dilihat pada Tabel 4.1 nampak dengan dosis $10 \mathrm{ng} / \mathrm{ml}\left(\mathrm{P} 1_{1}\right.$ dan $\left.\mathrm{P} 2_{1}\right)$ mampu memberikan efek peningkatan ketebalan uterus paling tinggi. Dimana menurut Roche (1998) mekanisme kerja kompleks protein IGF-1 pada folikel masak membantu LH membentuk androgen dan inhibin yang ada di sel granulosa.

Tabel 1. Rerata dan standar deviasi $(\mu \mathrm{m})$ ketebalan lapisan endometrium uterus setelah diberi perlakuan IGF-I SKB dan IGF-I recombinant mouse dengan berbagai dosis.

\begin{tabular}{ccc}
\hline Perlakuan Dosis & \multicolumn{2}{c}{ Ketebalan Lapisan Endometrium $(\mathrm{x} \pm$ SD) } \\
& IGF-I SKB & IGF-I Paten \\
\hline P0 & $261.35 \pm 66.92$ & $261.35 \pm 66.92$ \\
P1 & $383.64 \pm 118.23$ & $380.67 \pm 43.74$ \\
P2 & $303.11 \pm 52.28$ & $378.15 \pm 89.86$ \\
P3 & $281.93 \pm 166.02$ & $343.66 \pm 136.92$ \\
\hline
\end{tabular}

Keterangan :

$\mathrm{SKB}=$ diinjeksi Insulin-Like Growth Factor-I (IGF-I) dari serum kuda crossbreed bunting (SKB)

Paten = diinjeksi Insulin-Like Growth Factor-I (IGF-I) recombinant mouse

$\mathrm{P} 0=$ diinjeksi $0,1 \mathrm{ml} \mathrm{NaCl}$ fisiologis

P1 = diinjeksi $10 \mathrm{ng} / \mathrm{ml}$ IGF-I SKB atau IGF-I Recombinant mouse

P2 = diinjeksi $20 \mathrm{ng} / \mathrm{ml}$ IGF-I SKB atau IGF-I Recombinant mouse

P3 = diinjeksi $40 \mathrm{ng} / \mathrm{ml}$ IGF-I SKB atau IGF-I Recombinant mouse

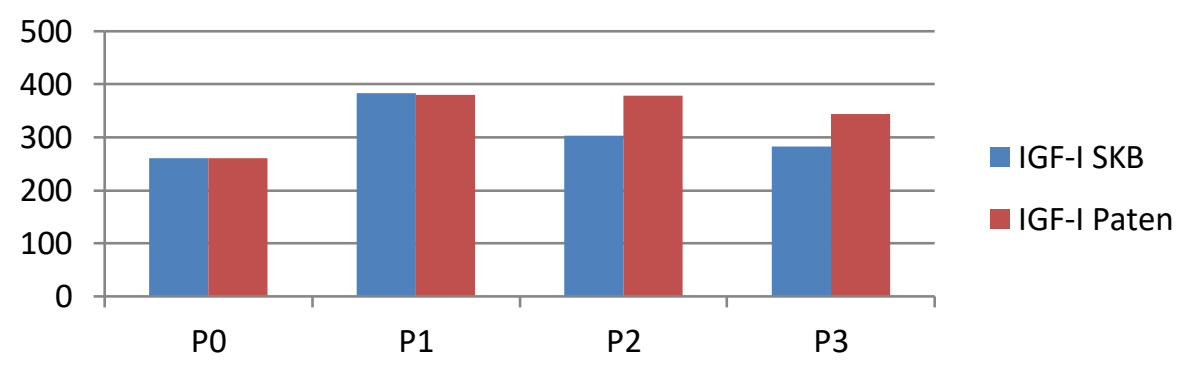

Gambar 1. Grafik perubahan ketebalan lapisan endometrium setelah diberi perlakuan IGF-I SKB dan IGF-I recombinant mouse. 

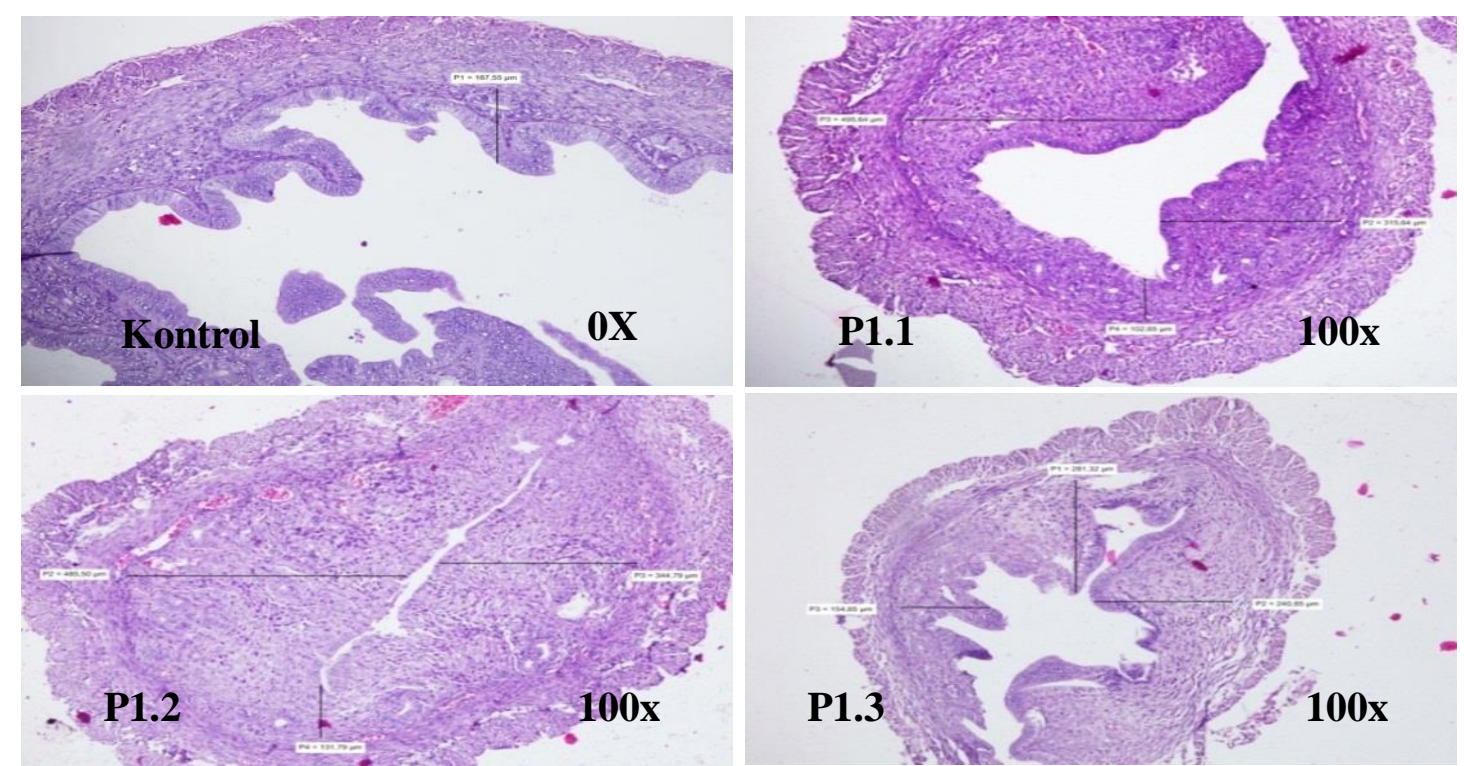

Gambar 2. Irisan melintang uterus yang memperlihatkan ketebalan lapisan endometrium. (Pewarnaan Haematoxylin-eosin, perbesaran 100x). Keterangan : Kontrol (261.35 $\mu \mathrm{m}), \mathrm{P} 1.1(383.64 \mu \mathrm{m}), \mathrm{P} 1.2(303.11 \mu \mathrm{m}), \mathrm{P} 1.3(281.93 \mu \mathrm{m})$.

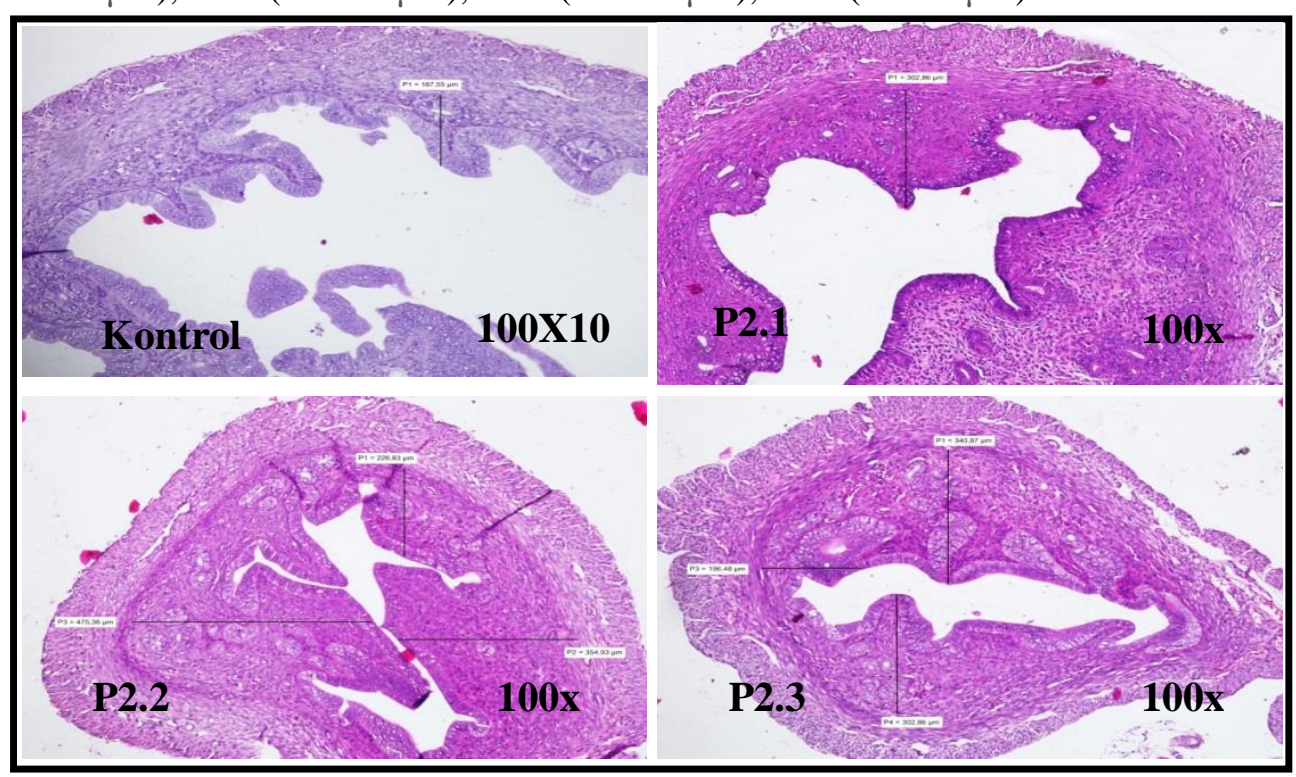

Gambar 3. Irisan melintang uterus yang memperlihatkan ketebalan lapisan endometrium, (Pewarnaan Haematoxylin-eosin, perbesaran 100x). Keterangan : Kontrol (261.35 $\mu \mathrm{m}), \mathrm{P} 2.1(380.67 \mu \mathrm{m}), \mathrm{P} 2.2(378.15 \mu \mathrm{m}), \mathrm{P} 2.3(343.66 \mu \mathrm{m})$.

Androgen dibawa ke sel granulosa diubah menjadi estradiol melalui proses aromatisasi yang dikontrol oleh enzim aromatase inhibitor yang dihasilkan oleh sel granulosa, kemudian dengan pengaruh FSH menyebabkan estradiol yang disekresikan meningkat. Estradiol merupakan salah satu unsur utama dari hormon estrogen, estrogen bereaksi terhadap uterus untuk meningkatkan massa endometrium dalam bentuk hiperplasi dan hipertrofi. Hormon estrogen diproduksi oleh sel-sel granulosa dari folikel pada fase antral hingga folikel de
Graff (Ismudiono dkk., 2010). Meningkatnya sekresi hormon estrogen yang distimulasi oleh kompleks protein IGF-1 mengakibatkan terjadinya proliferasi endometrium yang akan diikuti dengan meningkatnya afinitas kelenjar dan sekresi cairan ke lumen uterus (Klotz et al., 2001). Menurut Murphy dan Ghahari (1990) respon uterus terhadap estrogen merupakan mekanisme kompleks yang melibatkan banyak proses biokimia. Respon uterus pada estrogen ini yakni dengan proliferasi berbagai jenis sel yang ada didalamnya. Biosintesis 
estrogen di ovarium dipengaruhi oleh hormon pemacu folikel atau FSH (Folice Stimulating Hormon) (Ganiswara dkk., 1995). Kompleks protein IGF-I berpengaruh pada pembentukan $\mathrm{FSH}$, hormon $\mathrm{FSH}$ yang dihasilkan oleh hipofisis anterior berperan merangsang pertumbuhan folikel pada ovarium dan merangsang pembentukan reseptor LH pada sel-sel folikel ovarium (Peters, 1985). Pemberian IGF-1 Insulin-Like Growth Factor-I (IGF-I) dari serum kuda crossbreed bunting (SKB) dan IGF-1 Insulin-Like Growth Factor-I (IGF-I) recombinant mouse dengan dosis $20 \mathrm{ng} / \mathrm{ml}$ dan $40 \mathrm{ng} / \mathrm{ml}\left(\mathrm{P}_{2}, \mathrm{P}_{3}, \mathrm{P} 2_{2}, \mathrm{P} 2_{3}\right)$ terjadi peningkatan ketebalan endometrium yang tidak terlalu tinggi. Hal ini bisa sebabkan pada fase estrus dengan kadar estrogen tinggi meyebabkan umpan balik positif bagi hipofisa anterior untuk melepaskan LH, maka ketika kadar LH meningkat estrogen segera turun dan terjadi praovulasi. Kadar LH yang tinggi ini merupakan awal fase metestrus dan awal dimulainya ovulasi. Kadar estrogen yang tinggi ini dapat meningkatkan vaskularisasi dari endometrium (Ismudiono dkk., 2010). IGF-1 Insulin-Like Growth Factor-I (IGF-I) tersusun atas 70 asam amino dengan berat molekul yang relatif rendah yakni 7,65 kDa (Brzozowski et al., 2002) sedangkan IGF-1 Insulin-Like Growth Factor-I (IGF-I) dari serum kuda crossbreed bunting (SKB) memiliki 8 pita protein dengan berat molekul protein tersebut terletak diantara 7,65 $\mathrm{kDa}$ (Restiadi, 2013). Insulin-Like Growth Factor-I (IGF-I) dan IGF-1 Insulin-Like Growth Factor-I (IGF-I) recombinant mouse memiliki berat molekul yang sama.

Pemberian IGF-1 Insulin-Like Growth Factor-I (IGF-I) dari serum kuda crossbreed bunting (SKB) dan IGF-1 InsulinLike Growth Factor-I (IGF-I) recombinant mouse dengan dosis $10 \mathrm{ng} / \mathrm{ml}, 20 \mathrm{ng} / \mathrm{ml}$, dan $40 \mathrm{ng} / \mathrm{ml}$ pada perlakuan $\mathrm{P} 1, \mathrm{P} 2$, dan P3 menunjukkan perbedaan tidak nyata antar dosis pemberian hal ini dikarenakan saat pemberian perlakuan siklus estrus mencit tidak diseragamkan, dimana banyak variatif siklus estrus saat pemberiaan perlakuan. Perbedaan yang tidak nyata antar dosis juga diduga karena pengukuran ketebalan endometrium hanya menggunakan 4 titik pengukuran, dimana dari hasil yang ditunjukkan 4 titik pengukuran ini kurang mewakili dari seluruh lapisan endometrium.

\section{Kesimpulan}

Pemberian Insulin-Like Growth Factor-I (IGF-I) dari serum kuda crossbreed bunting (SKB) dapat menambah ketebalan lapisan endometrium mencit (Mus musculus). Pemberian IGF-I SKB mempunyai pengaruh yang sama dengan pemberian IGF-I recombinant mouse terhadap ketebalan lapisan endometrium mencit (Mus musculus). Dosis $10 \mathrm{ng} / \mathrm{ml}$ memberikan ketebalan lapisan endometrium paling tebal dibandingkan dengan dosis pemberian 20 $\mathrm{ng} / \mathrm{ml}$ dan $40 \mathrm{ng} / \mathrm{ml}$.

\section{Daftar Pustaka}

Acahe, H., A. Revel. 2006. Endometrial Receptivity Markers, The Journey To Succesfull Embryo Implantation. Tachtech Edical Journey.

Bearden, H., Joe., J.W. Fuquay, and S.T. Willard. 2004. Applied Animal Reproduction. Upper Saddle River. New Jersey.

Brzozowski, AM., E.J Dodson., GG Dosdon. 2002. Structural Origin Of The Functional Divergence Of Human Insulin-Like Growth Factor-I And Insulin. Biochemistry.

Douglas W. Cromey, M.S. 2004. Formaldehyde fixtative. SWEHSC Cellu-lar Imaging Core.

Ganiswara. 1995. Farmakologi dan Terapi Edisi 4. Gaya Baru: Jakarta.

Inoue, Ayako., Takeuchi, Sakae, and T. Sumio. 2005. Insulin-Like Growth Factor-I Stimulated DNA Replication in Mouse Endometrial Stroma Cells. Journal of Reproduction and Development. 51: 3 .

Ismudiono, Srianto, P., Anwar, H., Madyawati, S.P., Samik, A., dan Safitri E. 2010. Buku Ajar Fisiologi Reproduksi Pada Ternak. Airlangga University Press. Surabaya.

Klotz D.M., S.C. Hewitt, P. Ciana, M. Raviscioni, J. K. Lindezy, J. Foley, A. Maggi, R.P. Diagustine, and K.S. Kroach. 2001. Requirement of Estrogen Receptor- $\alpha$ In Insulin-like Growth Factor-I (IGF-I)-indunced Uterine Responses and in Vivo Evidence for IGF-I/Estrogen Re- 
ceptor Cross-talk. J. Bio. Chem. 277: 8531-8537.

Muchsin, R. 2009. Pengaruh Pemberian Monosodium Glutamate terhadap Histologi Endometrium Mencit (Mus musculus l) [Tesis]. Sekolah Pascasarjana. Universitas Sumatera Utara Medan.

Murphy, L.J., Ghahary A. 1990. Uterine Insulin-Like Growth Factor-1: Regulation of Expression and Its Role in Estrogen-Induced Uterine Proliferation. Endocrinology Rev. 11(3): 443-453.

Oner, J., Oner, H. 2007. Immunolocalization of Insuline-Like Growth Fac-tor I (IGF-I) During Preimplatation in Rat Uterus. Growth Hormone and IGF-1 research. 271-278.
Peters, A.R. 1985. Hormonal Control of Bovine Oestrus Cycle I. The Natural Cycle. Br. Vet. J. Reprod. Fertil. 47: 1-114

Roche, J.F. 1998. Controlls Of Foliculogenesis. J Theriology. 49: 457-467.

Restiadi, T.I. 2013. Potensi Biologis Bahan Bioaktif Insulin-Like Growth Factor-I Asal Serum Kuda Crossbreed G3-G4 Bunting pada Fertilisasi In Vitro Pada Sapi [Desertasi]. Fakul-tas Kedokteran Hewan. Universitas Airlangga. Surabaya.

Sulisdiani, P. 2016. Pengaruh Pemberian Insuline-Like Growth Factor-1 dari Serum Kuda Crossbreed Bunting terhadap Siklus Estrus Mencit (Mus musculus) [Skripsi]. Fakultas Kedokteran Hewan. Universitas Airlangga. Surabaya. 